\title{
Development of audit technology approach for performance improvement of faecal sludge treatment plant (IPLT) (Case study: IPLT Bawang in Tangerang City and IPLT Pecuk in Indramayu District)
}

\author{
Rydha Riyana Agustien ${ }^{1,{ }^{*}, \text { Prayatni Soewondo }}{ }^{2}$, and Arief Sudradjat ${ }^{2}$ \\ ${ }^{1}$ Research Institute for Housing and Human Settlements, Ministry of Public Works and Housing, J1. Panyawungan Cileunyi \\ Wetan Kabupaten Bandung, Indonesia \\ ${ }^{2}$ Faculty of Civil and Environmental Engineering, Institute Technology Bandung, Jl. Ganesha 10 Bandung 40132, Indonesia
}

\begin{abstract}
One of the infrastructure to support the achievement of the $100 \%$ sanitation target is IPLT. The development of audit technology approach needed for performance improvement of IPLT. The objectives of this research are to determine the weight of components technology priority that have affect to IPLT, assessing the achievement of performance in IPLT Bawang and IPLT Pecuk, and to determine the priority of performance improvement strategy in study area. This research consist of descriptive analysis about public sanitation condition in the study area by distributing questionnaires, scoring method analy sis of IPLT technology components using pairw ise comparison method to determine main priority of technology component, performance analy sis of IPLT Bawang and IPLT Pecuk using audit technology approach, and determining strategy of IPLT performance improvement. The weight of technology components that affect the performance of IPLT are humanware with weight 0,35 , orgaware with weight 0,29 , technoware with weights 0,24 and infoware with weight 0,13 . The value of performance achievement IPLT Pecuk is $60,2 \%$ and IPLT Bawang is $58,1 \%$. The priority of performance improvement strategy in IPLT Bawang are improvement strategies of humanware, technoware, infoware and orgaware, meanwhile in IPLT Pecuk are improvement strategies of technoware component, humanware, orgaware and infoware.
\end{abstract}

\section{Introduction}

Nowadays, the government has been conducting various program to achieve the RPJMN III (20152019) target, such as the achievement of $100 \%$ sanitation access. One of the sanitation aspects is the management of domestic waste water. Indicators and target of waste water development is open defecation free. To achieve the RPJMN targets, the government built sanitation facility on site and off site. In Indonesia, on site system with used septic tank is the most widely used. But, the effluent from septic tank is not yet eligible to be discharged into river because the high content of Biological Oxygen Demand (BOD) dan coliform. Without faecal sludge management, there will be contamination of pathogens into the environment and causing health damaged [1]. So, faecal sludge treatment plant needed to treat faecal sludge.

Faecal sludge treatment plant is one of the planed efforts to improve the treatment and to safe waste disposal. Based on Direktorat PPLP's data, nowadays Indonesia have 146 faecal sludge treatment plant which scattered in 23 provinces (out of 33 provinces) [2]. The condition of faecal sludge management in Indonesia is not functioning and not operating optimally due to constrains of technical and non technical aspect [2]. The main problem in faecal sludge treatment plant is a problem in the operation of faecal sludge treatment palnt. Based on Direktorat PPLP Dirjen Cipta Karya's data, the operating rate of faecal sludge treatment plant is $65 \%$ [3]. The problem in the management of faecal sludge treatment plant is lack of faecal sludge supply, lack of public knowledge about faecal sludge treatment and lack of willingness to pay of waste water retribution, lack of cooperation with private sector in term of suction faecal sludge [2].

One of the faecal sludge treatment plant that has been built is IPLT Bawang in Tangerang city dan IPLT Pecuk in Indramayu district. IPLT Bawang in Tangerang city is manage by Dinas Cipta Karya dan Penataan Ruang Tanggerang City. The physical condition of IPLT Bawang in Tangerang city is good and operated but not optimaly because the faecal sludge supply is more than the capacity [2]. IPLT

\footnotetext{
Corresponding author: rydhariy ana@gmail.com
} 
Pecuk Indramayu district manage by Dinas Kebersihan dan Pertamanan Indramayu District. The physical condition of IPLT Pecuk Indramayu district is good and operated but not optimaly because the faecal sludge supply is less than the capacity. Both of the faecal sludge used the pond system, but the same system have the diferrent problem.

Therefore it is necessary to do research about faecal sludge management with using development of audit technology approach to determine factor which have the effect in optimizing IPLT. When main factor is already known, advice can be formulated for performance improvement of IPLT.

\section{Methodology}

This study has been initiated with the identification of problems. Identification of problems has been carried out by observation, direct interviews with stakeholders, and the study of literature. The study of literature has been carried out by reading the article, book, journal or related research. Then, collected primary and secondary datas. Primary datas has been obtanined from questionnaires data, observation data, laboratory test result data and interviews data with stakeholders. Secondary datas has been obtained by the study of literature from the stakeholders.

This research has been carried out by audit technology approach. Audit technology approach is a systematic and objective evaluation conducted by auditors technology against technology assets to achieve the purpose of technology so as to provide added value and increase the performance of the auditee or stakeholder. Audit technology method has been set in Peraturan Kepala Badan Pengkajian dan Penerapan Teknologi No. 004 Tahun 2011 tentang Pedoman Audit Teknologi [4]. Component technology consists of technoware, humanware, infoware, orgaware which later became known as the audit technology approach method [5]. The audit technology approach method can used for analysis of management technology [6]. In this study, audit technology approach has used as a method to analyze and evaluate the suitability of the technology IPLT with planning and needs. So that the role and function of audit technology in this research is more focused on the role and function of technology management as the management of technology assets IPLT.

The next stage is a descriptive analys is of sanitary conditions of society by distributing questionnaires, weighting analysis of technology components IPLT using pairwise comparison, performance analysis IPLT with technology audit approach, determining IPLT performance improvement strategy.

The objectives of descriptive analys is of public sanitation conditions are to determine the condition and perceptions about waste water treatment and to determine ability to pay and willingness to pay about retribution of faecal sludge suction. This analys is has been carried out by distributing questionaires. The objective of weighting analysis of technology components IPLT is to determain main priority of technology component (technoware, humanware, infoware, dan orgaware (THIO)) which influential in determining performance of IPLT. This analys is using pairwise comparison method. Pairwise comparison method is a method for determining the ratio between an object with another object [7]. Mathematical formulation used in this method [8]. The objectives of permormance IPLT analysis are to determine the performance achievement IPLT in study areas and to determine performance improvement strategy in IPLT.

Performance IPLT analysis has been carried out by technoware analysis, humanware analysis, infoware analysis, and orgaware analysis. Technoware interpreted as the physical facilities to increase energy and human capabilities in to produce products and services. Technoware analys is has been carried by quality product assessment, planning criteria and installation functions. Technoware analysis processed quality product assessment has been carried out by the approach of determining the pollution index and BOD removal efficiency. Assessment planning criteria has been carried out by calculating the volumetric load and load surface processing unit. Installation function analysis has been carried out by looking at the performance of the installation through the method of Overall Equipment Effectiveness (OEE). OEE methods is usually used to measure performance in manufacturing such as research conducted by [9], [10], [11] and [12]. OEE calculation is based on three factors: availability, performance, and quality [13].

Humanware defined as people who have the skills or competence without which technoware useless. Humanware analysis in terms of the adequacy of human resources indicators, human resource competencies indicators, employment status indicators and performance assessment indicators. Infoware interpreted as written or electronic documents, which allows humanware to get information and learn faster. Infoware analysis in terms of required documents indicators, and ease of access to the document indicators. Orgaware interpreted as procedures and organizational structure terimplementassi that coordinate resources and activities to achieve goals. Orgaware analys is in terms of organization indicators, cooperation indicators and finance indicators.

\section{Overview IPLT in study areas}

\subsection{Overview IPLT Bawang in Tangerang City}

Based on Dinas Kesehatan Tangerang City's data in 2013, from 504.354 household in Tangerang city, 497.577 household $(97,5 \%)$ already have access to a private toilets to defecate. Tangerang city have waste water treatment plant which has built in 1982 and faecal sludge treatment plant (IPLT) which has been operate in 1999 (Anggraini, et al., 2016). IPLT 
Bawang located in Bawang street Perumnas Karawaci. This capacity is $\pm 70 \mathrm{~m}^{3} /$ day. The average of faecal sludge supply is $85 \mathrm{~m}^{3} /$ day. IPLT Bawang managed by Dinas Cipta Karya dan Penataan Ruang. The treatment unit in IPLT Bawang are imhoff tank, anaerobic ponds, facultatif ponds, oxidation pond, maturation pond and sludge drying bed [2].

\subsection{Overview IPLT Pecuk in Indramayu District}

Waste water treatment especially waste water and faecal sludge is managed by Dinas Kebersihan dan Pertamanan in Indramayu district (Perda Kabupaten Indramayu No. 8 Tahun 2008). Septic tank suction servis in 2011 is 270 household/year. Facilities and infrastructure are 1 unit faecal sludge truck and 1 unit IPLT Pecuk. The area of IPLT is $176,95 \mathrm{~m}^{2}$ with capacity $25 \mathrm{~m}^{3} /$ day. The average of faecal sludge supply is $2 \mathrm{~m}^{3} /$ day. The treatment unit in IPLT Pecuk are imhoff tank, anaerobic ponds, facultatif ponds, maturation pond and sludge drying bed [14].

\section{Result}

\subsection{Descriptive analysis of sanitary conditions of society in Tangerang City and Indramayu District}

According to the result of questionnaires, community in Tangerang city as much as $89 \%$ defecation using private toilets, $10 \%$ in public toilets and $1 \%$ in the river. The last estuary of feces is $93 \%$ in septic tank, $5 \%$ in river/draine and $2 \%$ in communal waste water treatment plant. Septic tank material which suitable with SNI 03-2398-2002 is 41\% septic tank. The percentage of people in Tangerang city who are not willing to improve his septic tank according to the standard is $99 \%$. The percentage of people who are willing to do the faecal sludge service scedule program (LLTT) is $47 \%$. The average of ability to pay in faecal sludge suction tariff is Rp. 333.960,/suction. The percentage of willingness to pay which suitable with retribution tariff is $42,0 \%$. The percentage of willingness to pay with tariff Rp. 20,000 ,- until Rp. 30,000 ,- per $\mathrm{m}^{3}$ is $13,39 \%$ and the percentage of people who are not willing to pay is $44,61 \%$.

According to the result of questionnaires, community in Indramayu district as much as $91 \%$ defecation using private toilets, $4 \%$ in public toilets and $5 \%$ in the river. The last estuary of feces is $89 \%$ in septic tank and $11 \%$ in river/draine. Septic tank material which suitable with SNI 03-2398-2002 is $26 \%$ septic tank. The percentage of people in Indramayu district who are not willing to improve his septic tank according to the standard is $94 \%$. The percentage of people who are willing to do the faecal sludge service scedule program is $54 \%$. The average of ability to pay in faecal sludge suction tariff is $\mathrm{Rp}$.
$346.950,-$ suction. The percentage of willingness to pay which suitable with retribution tariff is $53,0 \%$. The percentage of willingness to pay with tariff Rp. 40.000 ,- until Rp. 50.000 ,- per $\mathrm{m}^{3}$ is $4,23 \%$ and the percentage of people who are not willing to pay is $42,77 \%$.

\subsection{Weighting analysis of technology components IPLT using pairwise comparison}

The data used in the weighting analysis by using pairwise comparison method is consisten data from 25 respondents. The percentage of 25 consistent respondent are $28 \%$ of respondents from the central government, $20 \%$ from the Tangerang city, $20 \%$ from professionals, $16 \%$ from the Indramayu district government and $16 \%$ from the provincial government. Based on data Roscoe in Hill (1998) in [15] explained that in the simple experimental research with tight control, the number of respondents can be done with a sample of 10 to 20 respondents. So the data from respondents consistently declared valid and can represent for research.

Based on the results of the assessment, the variable priority or have the greatest weight is humanware variable as much as 0,35 . The next priority are orgaware variable with a weight of 0,29 , technoware variable with a weight of 0,24 and infoware variable with a weight of 0,13 . Comparison between the variable weights can be seen in Figure 1 . The 10 indicators / parameters of the most influential are the human resources training parameter is amounted to $11,14 \%$, installation function indicators $9,02 \%$, employee performance assessment indicators is amounted to $8,14 \%$, planning criteria indicator is amounted to $8,02 \%$, the adequacy of human resources indicator of is amounted to $7,29 \%$, refined quality indicators is amounted to $6,95 \%$, operational and mainterance (OM) availability parameter is amounted to $4,70 \%$, human resources education parameter is amounted to $4,67 \%$, an indicator of the legal basis for financing the management IPLT is amounted to $4,42 \%$, and employment status indicator is amounted to $3,45 \%$. The result of this research is different from the results of research conducted by Anggraini et. al. in 2016. Based on Anggraini et. al. in 2016 research, the priority of IPLT component are technoware variable with a weight of 0,384 , humanware variable with a weight of 0,250 , orgaware variable with a weight of 0,212 and infoware variable with a weight of 0,154 . The differences of both research is the research conducted by Anggraini et. al. in 2016, the overall respondents who filled out weighting questionnaires works as a researcher so the attention in technoware component. In this study, the respondent's professional backgrounds are more varied as described previously. 


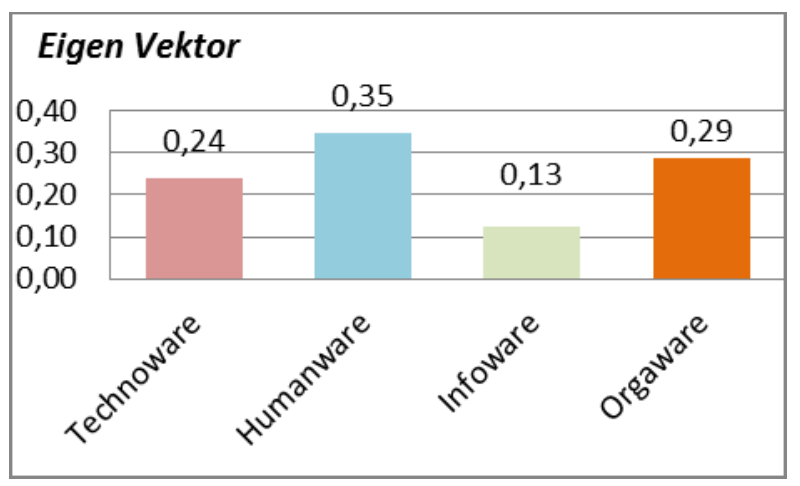

Fig. 1. The comparison between variable weights

\subsection{Performance analysis IPLT with audit technology approach}

\subsubsection{Technoware Component Analysis of Performance IPLT Bawang and IPLT Pecuk}

Technoware value is the incorporation from the value of quality product assessment, planning criteria and installation functions that have been previously analyzed. Technoware value in IPLT Pecuk is smaller than technoware value in IPLT Bawang. Technoware value in IPLT Pecuk is amount to 0,3987 while technoware value in IPLT Bawang is amount to 0,4963 . Technoware perfect score is equal to 0,8797 . When compared with a perfect technoware score, then the technoware value IPLT Pecuk is $45 \%$ while the technoware value IPLT Bawang is $56 \%$.

\subsubsection{Humanware Component Analysis Performance IPLT Bawang and IPLT Pecuk}

Humanware value is the incorporation from the adequacy of human resources indicators value, human resource competencies indicators value, employment status indicators value and performance assessment indicators value. Humanware value in IPLT Pecuk is smaller than humanware value in IPLT Bawang. Humanware value in IPLT Pecuk is amount to 0,5823 while humanware value in IPLT Bawang is amount to 0,5860 . Humanware perfect score is equal to 0,9248 . When compared with a perfect humanware score, then the humanware value IPLT Pecuk is $63,0 \%$ while the humanware value IPLT Bawang is $63,4 \%$.

\subsubsection{Infoware Component Analysis of Performance IPLT Bawang and IPLT Pecuk}

Infoware value is the incorporation from the required documents indicators value and ease of access to the document indicators value. Infoware value in IPLT Pecuk is bigger than Infoware value in IPLT Bawang. Infoware value in IPLT Pecuk is amount to 0,3499 while infoware value in IPLT Bawang is amount to 0,2002 . Infoware perfect score is equal to 0,4440 . When compared with a perfect Infoware score, then the Infoware value IPLT Pecuk is $79 \%$ while the Infoware value IPLT Bawang is $45 \%$.

\subsubsection{Orgaware Component Analysis of Performance IPLT Bawang and IPLT Pecuk}

Orgaware value is the incorporation from the organization indicators value, cooperation indicators value and finance indicators value. Orgaware value in IPLT Pecuk is bigger than orgaware value in IPLT Bawang. Orgaware value in IPLT Pecuk is amount to 0,5406 while orgaware value in IPLT Bawang is amount to 0,5248 . Orgaware perfect score is equal to 0,8622 . When compared with a perfect orgaware score, then the orgaware value IPLT Pecuk is $63 \%$ while the orgaware value IPLT Bawang is $61 \%$.

\subsection{Performance Achievement Analysis of IPLT}

IPLT technology component values are calculated by merge technoware, humanware, infoware and orgaware value. Performance achievement value in IPLT Pecuk is bigger than performance achievement value in IPLT Bawang. Performance achievement value in IPLT Pecuk is amount to $60,2 \%$ while performance achievement value in IPLT is amount $58,1 \%$. IPLT performance evaluation results are shown in Table 1.

Table 1. IPLT performance evaluation results

\begin{tabular}{|l|c|c|c|}
\hline $\begin{array}{c}\text { Technology } \\
\text { Component }\end{array}$ & $\begin{array}{c}\text { Perfect } \\
\text { Score }\end{array}$ & $\begin{array}{c}\text { Indramayu } \\
\text { Score }\end{array}$ & $\begin{array}{c}\text { Tangerang } \\
\text { Score }\end{array}$ \\
\hline Technoware & 0,8797 & 0,3987 & 0,4963 \\
\hline Humanware & 0,9248 & 0,5823 & 0,5860 \\
\hline Infoware & 0,4440 & 0,3499 & 0,2002 \\
\hline Orgaware & 0,8622 & 0,5406 & 0,5248 \\
\hline Totaly & 3,1106 & 1,8716 & 1,8073 \\
\hline $\begin{array}{l}\text { Performance } \\
\text { Achievement of IPLT }\end{array}$ & $\mathbf{6 0 , 2 \%}$ & $\mathbf{5 8 , 1 \%}$ \\
\hline
\end{tabular}

\subsection{Determining IPLT Performance Improvement Strategy}

Recommendations for improved performance IPLT Bawang in Tangerang City are the implementation of human resource training for managing waste treatment plant; dredging of faecal sludge in treatment unit of IPLT; upgrading of treatment units design; need execution LLTT; supplying program of septic tank which suitable with standard; establish cooperation with the community in supporting the LLTT program; collate documents SOP operation, maintenance, repair and $\mathrm{K} 3$; preparing technical documents and IPLT monitoring, assessing employee performance against IPLT manager; increased ease of access to documents; and strengthening the management and financing IPLT regulation. The 
formulation of these recommendations based on analysis of improvement priority IPLT Bawang in accordance with Figure 2.

Recommendations for improved performance IPLT Pecuk in Indramayu district are increasing equalization tank with bar screen before imhoff tank; dredging of faecal sludge in treatment unit of IPLT; necessary implementation LLTT; supplying program of septic tank which suitable with standard; improve the competence of human resources by improving education and implementation of human resource training for managing waste treatment plant; the increase in funding sources $\mathrm{OM}$; increasing the number of human resources; cooperation with private and public companies in support LLTT program; monitoring of faecal sludge truck; strengthening regulation of the management and financing of waste treatment plant; as well as complete the licensing documents and SOP K3. The formulation of these recommendations based on analysis of improvement priority IPLT Pecuk accordance with Figure 3.

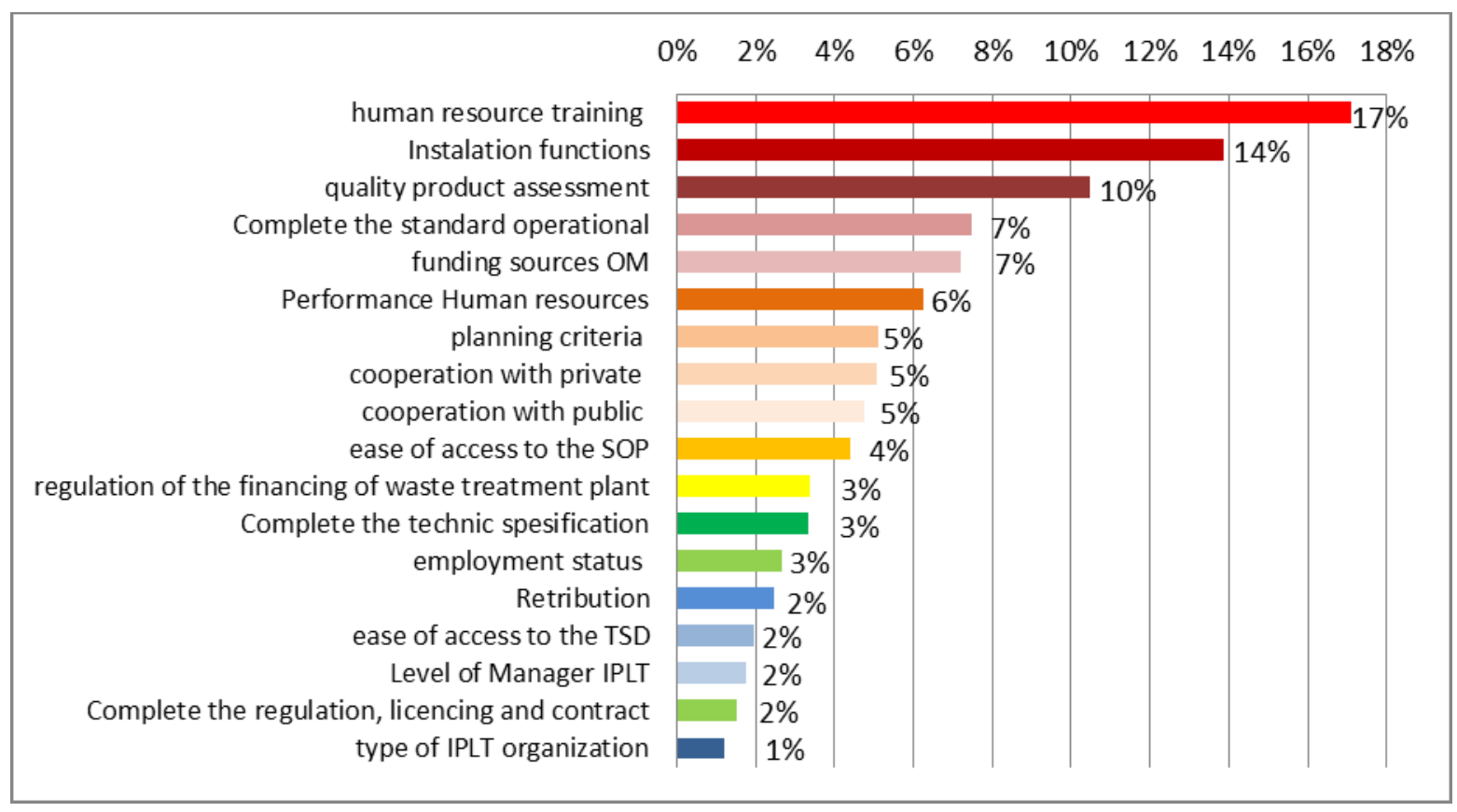

Fig. 2. Improvement priority IPLT Bawang

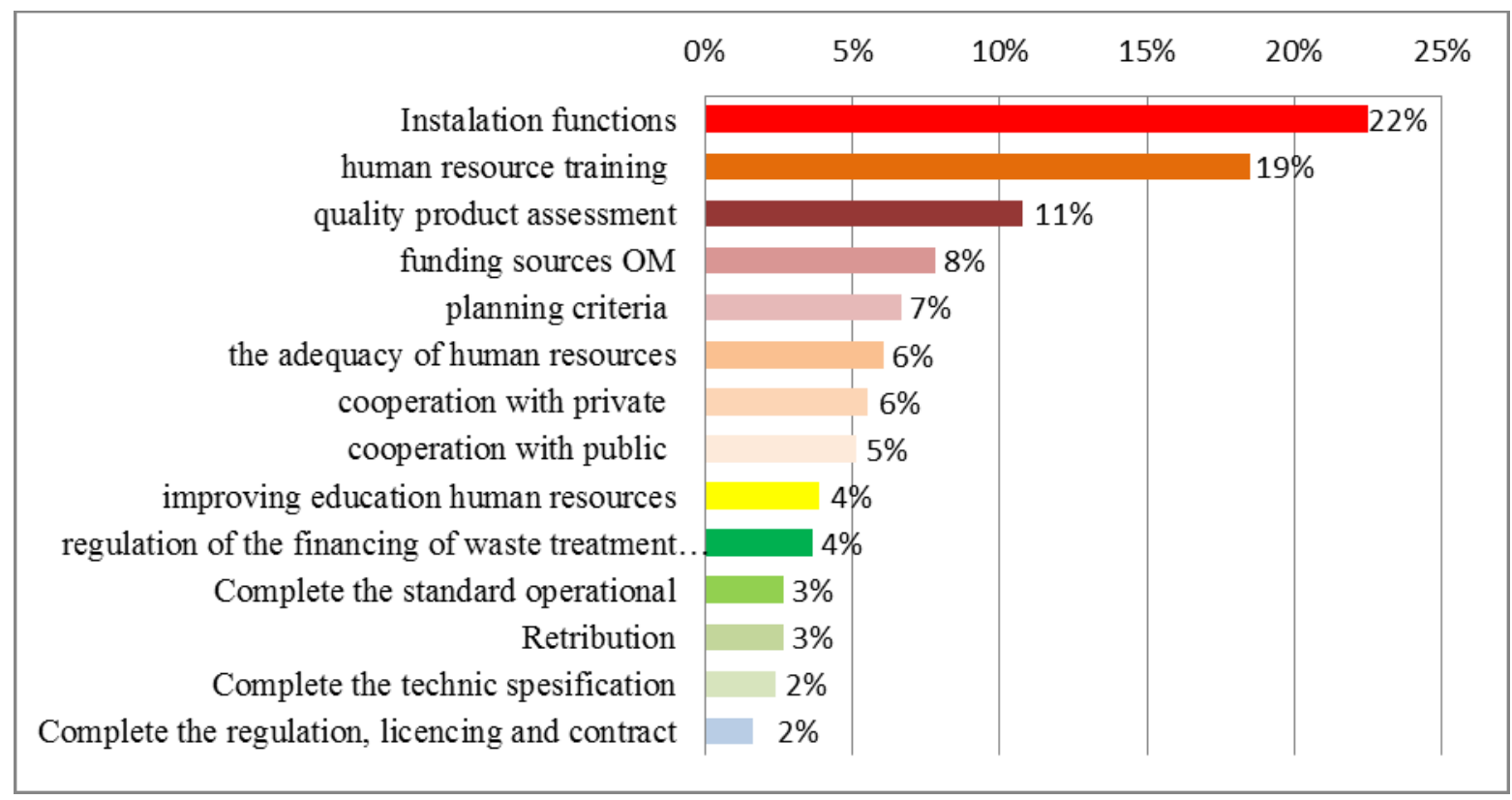

Fig. 3. Improvement priority IPLT Pecuk 


\section{Conclusion}

1. The weight of technology components that affect the performance of IPLT are humanware with weight 0,35 , orgaware with weight 0,29 , technoware with weights 0,24 and infoware with weight 0,13 .

2. Performance achievement value in IPLT Pecuk is amount to $60,2 \%$ while performance achievement value in IPLT is amount $58,1 \%$.

3. The priority of performance improvement strategy in IPLT Bawang are improvement strategies of humanware component, improvement strategies of technoware component, improvement strategies of infoware component and improvement strategies of orgaware component.

4. The priority of performance improvement strategy in IPLT Pecuk are improvement strategies of technoware component, improvement strategies of humanware component, improvement strategies of orgaware component and improvement strategies of infoware component.

\section{References}

1. Strande, L, The Global Situation, Faecal Sludge Management, L. Strande, M. Ronteltap, \& D. Brdjanovic, , London: IWA Publishing, 1-14, 2014.

2. Anggraini, F., Nuraeni, R., Yudiarti, I., Rosa, Y., Prayudi, T. R., Effendi, R. R., Pamekas, R., Audit Teknologi Sistem Instalasi Pengolahan Lumpur Tinja (IPLT), Bandung: PT. Kiblat Buku Utama, 2016.

3. Anggraini, F., \& Nuraeni, R., Diagnosis Kinerja Instalasi Pengolahan Lumpur Tinja (IPLT), Widyariset, Vol. 1 No. 1 Hal. 87-99, 2015.

4. Pusat Audit Teknologi, Framework, Kode Etik dan Standar, Pedoman Umum Audit Teknologi, Jakarta: Pusat Audit Teknologi-BPPT, 2011.

5. Toloui, A., \& Matin, Y. A., Measuring Technological Level and Capability of the Industries in East Azerbaijan and Providing Prover Strategies for Improvement and Promotion of Technology, Journal of Basic and Applied Scientific Research, 2 (4) 3664-3669, 2012.

6. Zaker, A. R., Tajik, H., \& Bahramifaraz, F., Analyzing the Effect of Management of Technology Transfer in Science and Technology Parks for Wealth Creation, Case Study: Science and Technology Park of Tehran University, International Research Journal of Applied and Basic Science, Vol. 4 (10): 3427-3433, 2013.
7. Padmowati, R. d., Analisis Teknik Indeks Konsistensi harmonik pada metode Analytical Hierarchy Process, Bandung: LPPM-Universitas Katolik Parahyangan, 2012.

8. Febrinata, Perancangnan Key Performance Indicators (KPI) Menggunakan Metode Balance Scorecard dan Pairwise Comparison di PT. Aston System Indonesia, Surakarta: Universitas Sebelas Maret, 2013.

9. Samad, M. A., Hussain, M. R., \& Asrafuzzaman, M., Analysis of Performace by Overall Equipment Effectiveness of the CNC Cutting Section of a Shipyard, ARPN Journal of Science and Technology, Vol. 2 No. 11 pp. 1091-1096, 2012.

10. Zandieh, S., Tabatabael, S. A., \& Ghandehary, M., Evaluation of Overall Equipment Effectiveness in Continuous Process Production System of Condensate Stabilization Plant in Assalooyeh, Interdisciplinary Journal of Contemporary Research in Business, Vol. 3 No. 10 pp. 590-598, 2012.

11. Boban, B., \& Joseph E., J., Enchancing Overall Equipment Effectiveness for a Manufacturing Firm through Total Productive Maintenance, Enchancing Overall Equipment Effectiveness for a Manufacturing Firm through Total Productive Maintenance, Vol. 3 Issue. 8 pp 425-429, 2013.

12. Nayak, D., Kumar M N, V., Naidu, G., \& Shankar, V., Evaluation of OEE in a Continuous Process Industry on an Insulation Line in a Cable Manufacturing Unit, International Journal of Innovative Research in Science, Engineering and Technology, Vol. 2. Issue. 5 pp. 1629-1634, 2013.

13. Rahmad, Pratikto, \& Wahyudi, S., Penerapan Overall Equipment Effectiveness (OEE) dalam Implementasi Total Productive Maintenance (TPM) (Studi Kasus di Pabrik Gula PT. "Y"), Jurnal Rekayasa Mesin, Vol. 3 No. 3 Hal. 431437, 2012.

14. Dinas Kebersihan dan Pertamanan Kab. Indramayu, Standar Operasional dan Prosedur IPLT Pecuk Kabupaten Indramayu, Indramayu: Dinas Kebersihan dan Pertamanan Kabupaten Indramayu, 2015.

15. Putra, R. R., Analisis Faktor Penentu Pengembangan Sistem Pengolahan Air Limbah Terpusat Kota Tangerang (Studi Kasus: Kecamatan Tangerang), Bandung: Institut Teknologi Bandung, 2016.

\footnotetext{
* Corresponding author: rydhariy ana $@$ gmail.com
} 